\title{
AUXILIARY WILL IN ENGLISH AND ITS SERBIAN EQUIVALENTS
}

\begin{abstract}
This study seeks to investigate auxiliary wiLl from an English - Serbian contrastive perspective. It aims to: 1) identify the translation equivalents (TEs) of WILL in Serbian and reach conclusions about similarities and differences between the two languages, and 2) observe and discuss the nature of Serbian counterparts. A unilateral contrastive analysis was carried out on the sentential corpus comprising the excerpts from two acclaimed English novels and their published Serbian translations. The TEs of epistemic wILL and dynamic wILL are discussed concerning semantic peculiarities surfacing in translation. Specifically, the type of a modal meaning, non-factuality, and the speaker's commitment to the realisation of the situation referred to are pointed out.
\end{abstract}

Key words: will, epistemic modality, dynamic modality, future time, tense, Serbian

\section{Introduction}

A large body of research informs us that modality is an omnipresent phenomenon cross-linguistically. Its linguistic manifestations have been in the focus of studies within more than one academic discipline (philosophy, linguistics, semantics, pragmatics, philosophy of language) and approached from different perspectives. ${ }^{1}$ Being fairly uncontroversial expressions of linguistic modality, modal verbs are probably the most extensively studied. English modal auxiliary verbs, in particular, have provided the basis for numerous typological and contrastive studies aimed at producing insights on modality encodings in considerably less explored languages. In line with these trends of linguistic enquiry, the past decades have seen a surge of interest in Serbian modals from an English - Serbian contrastive perspective. Auxiliary WILL ${ }^{2}$ has fallen within the scope of the extensive contrastive research on epistemic modality (TrbojevićMilošević 2004) and a small-scale study focused on dynamic modality in the two languages (Radovanović 2017). Well worthy of mention is the study focused on WILL in epistemic and dynamic use and its equivalents in Serbian (Prtljaga 2008). Besides,

\footnotetext{
"Faculty of Hotel Management and Tourism, University of Kragujevac, Vojvođanska bb, 36210 Vrnjačka Banja, Serbia; e-mail: aleksandra.radovanovic@kg.ac.rs

${ }^{1}$ For an extensive overview, see Depraetere (2016) and references therein.

${ }^{2}$ Following typographic conventions used by Palmer (1986), sMALl CAPITALs are used for verbs.
} 
WILL has also been addressed within the research on expressing temporality (Novakov 2008) and the future time reference (Cochrane and Kalogjera 1987; Kalogjera 1971) in the same pair of languages.

Taken together, the above pieces of research have yielded important theoretical and empirical results. Especially valuable are the lists of linguistic items used in Serbian to cover various functions and meanings of the English verb, typically provided along with illustrative examples. There is room for further research, however, since the issues of the shifts of modal meaning in translation have insufficiently been addressed so far. Therefore, this study seeks to complement the existing research and aims to: 1) identify the translation equivalents (TEs) of wILL in Serbian and reach conclusions about similarities and differences between the contrasted languages, and 2) observe and discuss the nature of the Serbian counterparts. Due to the unique status of wILL in English verb paradigm, such a study may offer informative insights and advance our understanding of expressing modal and temporal meanings in the investigated languages.

Following a brief review of the approaches to the auxiliary in question, the theoretical framework is elaborated in the methodology section. The central part of the study is devoted to the analysis and discussion of epistemic WILL and dynamic WILL and their TEs in Serbian. The findings are summarized in the conclusion.

\section{Auxiliary wILL in English language theory and description}

The nature of linguistic expression and language structure is characterised by great complexity. Although grammatical categories tend to correlate with particular semantic or functional domains (e.g. tense - temporality, mood-modality, aspect-aspectuality), a lack of one-to-one correlation is commonly observed in languages. This means that one semantic category may be encoded by a variety of grammatical markers, while a grammatical category can be used to express more than one semantic category. On these grounds, WILL may be taken to be a member of modality and/or tense system, which gives this auxiliary an exceptional status in the English verb paradigm. That is, wILL may be considered as a means to indicate modality or temporality, as in (1) and (2) respectively:

(1) Louisa, will you please be quiet! (Salkie 2010: 192)

(2) My driver's licence will expire at the end of the month. (Novakov 2008: 20)

In (1), wILL undoubtedly has the function of a modality marker. Based on its morpho-syntactic properties, wILL is the most straightforward of the English modal auxiliaries as it exhibits all the properties of the members of this distinctive set of verbs (Huddleston and Pullum 2002: 106-108). ${ }^{3}$ In addition to the so-called NICE ${ }^{4}$

\footnotetext{
${ }^{3}$ In this respect, wiLl shares great similarity with CAN (Huddleston and Pullum 2002: 106).

${ }^{4}$ The acronym standing for the following properties of the central modals: Negation, Inversion, Code, and
} 
properties, it has the following distinctive features of modal auxiliaries: it has only primary forms, it does not show any agreement with the subject, it takes bare infinitival complements, it is required in remote conditionals, and the use of its preterit with the modal remoteness meaning is much less restricted than is the case with other verbs (Huddleston and Pullum 2002: 106). Also, wILL shares the same semantic properties with other English central modals, i.e. it is capable of conveying at least two modal meanings which, however, have been labelled differently according to the adopted categorisation strategies and defining criteria. ${ }^{5}$

Unlike wILL in (1), wILL in (2) hardly allows for such a straightforward categorisation. From a pedagogical grammar point of view, it functions as a tense auxiliary used to form the future simple tense, which is the most frequent and the most neutral way to express futurity in English (Comrie 1985; Novakov 2008; Wekker 1976). Under this view, WILL shares almost the same function with primary auxiliaries BE and HAVE. Yet, from the linguistic standpoint, the distinction between modal wILL in (1) and pure future, or neutral futurity, wILL in (2) is very far from being clear. At least two issues arise: 1) whether there are two wILLs, one of which is a temporality marker and the other of which is a modality marker, and 2) if there is only one wILL, whether it is temporal or modal. As Sarkar (1998: 115) puts it, the question is "Is wILL part of the tense system or the modal system or is it simply homonymous?". The contentious issues relate directly to the perennial question of whether English has a future tense which has sparked off the debate surrounding the future tense in a general linguistic theory. ${ }^{6}$

Although several grammatical criteria were formulated to empirically show the difference between future wILL and modal wILL (Salkie 2010; Wekker 1976), the positions taken are more strongly dependent upon semantic basis. ${ }^{7}$ Being a particularly versatile modal, wILL boasts a broad array of meanings the approaches to which have been varied. As with other modals, two traditions in semantic analyses have been followed. According to one, each modal is considered to be monosemous, which means that it has a core meaning evident in all its uses (Depraetere and

Emphasis (Huddleston and Pullum 2002; Palmer 1990).

${ }^{5}$ Depraetere and Reed (2006: 277-280) offer a detailed overview of the approaches to the classification of modal meanings.

${ }^{6}$ The main issue under the debate is "whether such a category is justified in linguistic theory in the first place, as a tense" (Comrie 1985: 43). For a review of the arguments presented in the debate on WILL, see Radovanović (2018).

${ }^{7}$ In this respect, wiLl has been considered as:

- a tense auxiliary used to make a future tense which has only temporal use and meaning (Salkie 2010), or can have additional modal uses and meanings (Comrie 1985);

- a modal auxiliary in all of its uses (Huddleston and Pullum 2002; Klinge 2005);

- a modal auxiliary which has secondary temporal uses (Leech 2004; Palmer 1986, 1990);

- an auxiliary which has two sets of meanings, none of which prevails (Bergs 2010; Sarkar 1998). 
Reed 2006: 283). As regards wILL, this view has been adopted in the construction grammar approach (Bergs 2010) and by the advocates of a unified semantics of wILL. Sarkar (1998), for instance, claims that the semantics of wILL can be decomposed into a composition of the semantics given to a modal contribution and the temporal contribution of the present tense, so each occurrence of WILL is simultaneously a modal and a tense morpheme.

Far more prevalent, particularly in traditional literature (Huddleston and Pullum 2002; Leech 2004; Palmer 1986, 1990), and hence, taken in this study, is the polysemous view of modals. A polysemy analysis treats a modal as conveying at least two independent meanings which may not be clearly distinct. In this line of thought, the semantic portrayal of WILL is characterised by a great variety and terminological inconsistencies. By way of illustration, Palmer (1974: 104-113) discerns futurity, volition, insistence, characteristic, and inference, whereas Leech (2004: 85-87) also singles out five meanings of wILL, but relies on somewhat different notions of future time, prediction/predictability, intention, willingness and insistence. Placing a stronger emphasis on modality concepts, Sarkar (1998: 94-95) categorizes the semantics of WILL into futurity, epistemic modality, dynamic modality, capability/generic, and directives. Starting from Leech's (2004) proposal, Klinge ${ }^{8}$ (2005: 174) offers a list of seven sentences illustrative of a range of potential meanings of utterances containing wILL: future time, willingness, insistence, intention, predictability, characteristic behaviour and order. However, it is questionable whether these lists account for the full range of meanings of this auxiliary modal (Klinge 2005; Sarkar 1998).

\section{Methodology}

\subsection{Methods and the data}

The methodological framework of the study comprises a contrastive and a descriptive analysis, supported by quantitative data. Following the key tenets of theoretical contrastive linguistics, the analysis makes use of the semantically based tertium comparationis, i.e. the notion of equivalence involves the concept of translation equivalence (Đorđević 1994; Jaszczolt 2003). A unilateral analysis was carried out on the sentential corpus compiled for the research purposes: two acclaimed English novels ${ }^{9}$ were searched for the relevant instances of wILL, ${ }^{10}$ and their translations were then excerpted from the novels published in Serbian. The procedure yielded a

\footnotetext{
${ }^{8}$ The author (Klinge 2005: 174) also observes that will takes the prize among English modals when it comes to the number of meanings allegedly uncovered in traditional literature.

${ }^{9}$ The examples in the study are accompanied by an abbreviation identifying the text. These, along with the bibliographical descriptions of the textual material, are provided in Sources.

${ }^{10}$ The analysis focuses on wILL in simple sentences or independent clauses.
} 
corpus comprising 687 examples in both languages. The TEs were manually counted, classified and discussed concerning the concepts and notions outlined below.

\subsection{Theoretical framework}

The study takes an eclectic approach and relies on the theoretical tools of the relevant descriptive grammars, theoretical and contrastive studies mentioned above. As regards Serbian, it largely relies on the insights offered in the latest comprehensive syntax (Piper et al. 2005). Following a long-standing approach according to which future-time reference falls under the scope of modality, the analysis adopts the view that "where there is a wILL, there is a modal" (Klinge 2005). Based on the outcomes of a literature review, the utterances containing wILL are ascribed the following features: non-factuality, the speaker's expression of his commitment to the truth of the proposition, i.e. the realisation of the situation referred to, and expressing modal meanings.

Two modality types are taken as the cornerstones of the analysis as they easily accommodate concepts and notions related to the semantics of WILL mentioned above but viewed through the lenses of modality. Hence, we differentiate between epistemic modality ${ }^{11}$ and dynamic modality meanings of wILL, i.e. epistemic WILL and dynamic WILL. Much in line with recent approaches (Collins 2009 inter alia), we distinguish between two epistemic meanings of wILL: predictaability, i.e. a central/epistemic meaning (Huddleston and Pullum 2002: 188), and prediction, typically labelled futurity elsewhere. As for dynamic modality, the study generally subscribes to Huddleston and Pullum's (2002: 52) view that it "concerns the properties and dispositions of persons, etc., referred to in the clause, especially by the subject." Hence, it comprises propensity and volition (Huddleston and Pullum 2002: 192-194), or, in Palmer's (1990: 133) terms, volition, power and habit. Given that volition can be accounted for deontically, we do not single out deontic modality as a separate category of modal meaning, in which respect the analysis slightly deviates from previous proposals (e.g. Collins 2009; Huddleston and Pullum 2002). It should be noted that the two are not contrasting meanings of wILL (Huddleston and Pullum 2002: 193). Rather, the notion of prediction is to an extent incorporated in most utterances containing wILL so that epistemic meaning tends to combine with the dynamic meanings (Leech 2004; Wekker 1976). Since making strict distinctions may not always be possible, the examples in which non-epistemic meaning turns out to be more salient are treated under the rubric of dynamic wILL.

\footnotetext{
${ }^{11}$ Epistemic modality is a complex domain which may be defined based on various concepts (e.g. logical possibility and necessity, truth, probability, judgment, conclusion). In a nutshell, it deals with belief, knowledge, truth, etc. in relation to the proposition.
} 


\section{Results and discussion}

\subsection{Translation equivalents of wILL in Serbian}

Of 687 examples in our data, largely prevalent are the instances of wILL with a simple infinitive. Continuous infinitive features in 39 instances and the prefect infinitive is found in only 8 examples. Overall, epistemic wiLL has overwhelming dominance. The pervasiveness of prediction wILL (479 instances, 69.7\%) might have been expected as it is the most frequent way of expressing future time in English (Wekker 1976). In its predictability meaning, wILL appears only in 7 instances (1\%), whereas dynamic WILL is found in 201 examples $(29.3 \%)$.

The findings of the contrastive analysis are largely in line with the previous relevant studies mentioned in the introduction. The substantial majority of translations are congruent, i.e. the so-called future tense is found in both languages. Since the existence of the seemingly equivalent forms may not prevent translation divergence (see Johansson 2007), the analysis has also revealed that there are non-congruent (divergent) translations of wILL, with linguistic items belonging to different morphosyntactic and lexical categories in the two languages, as shown in Table 1.

\begin{tabular}{|c|c|c|c|c|}
\hline \multirow{2}{*}{\multicolumn{2}{|c|}{ TEs }} & \multicolumn{2}{|c|}{ Epistemic WILL } & \multirow{3}{*}{$\frac{\text { Dynamic wILL }}{\checkmark}$} \\
\hline & & \multirow{2}{*}{$\frac{\text { Prediction }}{\checkmark}$} & \multirow{2}{*}{$\begin{array}{c}\text { Predictability } \\
\checkmark \checkmark \text { (ВітI) }\end{array}$} & \\
\hline \multirow{5}{*}{ Tense and mood } & future 1 & & & \\
\hline & futuroid & & & $\checkmark$ \\
\hline & present tense & $\checkmark$ & $\checkmark$ & $\checkmark$ \\
\hline & conditional present & $\checkmark$ & & \\
\hline & imperative & & & $\checkmark$ \\
\hline \multirow{2}{*}{ Adverb } & sigurno/svakako & $\checkmark$ & $\checkmark$ & \\
\hline & verovatno & & $\checkmark$ & \\
\hline \multirow{3}{*}{ Modal verb } & MORATI & $\checkmark$ & & \\
\hline & TREBATI & $\checkmark$ & & \\
\hline & MOĆI & & & $\checkmark$ \\
\hline Semi-modal & HTETI & & & $\checkmark$ \\
\hline Modal lexeme & ŽELETI & & & $\checkmark$ \\
\hline \multirow{2}{*}{ Miscallenous } & ODBITI & & & $\checkmark$ \\
\hline & idiomatic phrase & $\checkmark$ & & $\checkmark$ \\
\hline
\end{tabular}

Table 1. Translation equivalents of wILL 


\subsection{Epistemic WILL}

In Serbian, future 1 is the general future tense which, in its indicative use, locates events after the moment of speech. According to the prescriptive rules, it is the periphrastic tense made by means of the auxiliary HTETI in a clitic form and the infinitive of the lexical verb, but which can also occur as a flective form. It is commonly considered both a formal and translation equivalent to the English wILL future (Cochrane and Kalogjera 1987). Reasonably, then, in a great majority of instances, future 1 of both perfective and imperfective verbs ${ }^{12}$ is found in translations of prediction wILL, irrespective of the type of its infinitival complement, as the examples below illustrate.

(3) In five years we'll know. (SAT)

(3s) To ćemo znati kroz pet godina. (suB: 174)

(4) ... I will be making a short speech myself tonight. (UNC)

(4s) ... večeras ću i ja održati kratak govor. (BU: 174)

(5) You'll have forgotten all about this cold unpleasant walk by then. (UNC)

(5s) Do tada ćeš sasvim da zaboraviš ovu hladnu i neprijatnu šetnju. (BU: 55)

In only 17 (3.5\%) instances, the translators deviate from this standard practice.

The Serbian present tense, just like its English counterpart, is characterised with the temporal polyvalence, i.e. it has the capacity of being transposed to denote past or future (Piper et al. 2005: 382-386). A transposition to future is characteristic of imperfective verbs which denote planned or fixed events, which accounts for only one instance of this verb form in our data (6s).

(6) Tonight she'll be home for the first time in six months... (SAT)

(6s) Večeras dolazi kući prvi put... (suB: 11)

(7) Any moment now he'll be ready... (UNC)

(7s) Samo što se nije spremio... (Bu: 93)

Since prediction wILL may be taken to involve a minimal component of modal meaning, the TE might be a reasonable option in (6s). However, subtle differences in the shades of meaning can be intuitively felt. Notably, the TE shows a greater degree of immediacy since WILL in (6) has less focus on matrix time. In a parallel fashion, even greater immediacy of the predicted event is evident in one instance of rendering WILL by a prospective construction (7s). Also, the TE in (6s) seems to convey the speaker's assurance of the event of her arrival. The situation in (6) is interwoven with some degree of modality, whereas modal shading attaching to wILL seems to be lost in Serbian modally unqualified assertion. In fact, the TE fails to convey the predictive meaning since it presents the predicted event as an objective reality. As regards the use of present tense

\footnotetext{
${ }^{12}$ In Serbian, verbal aspect is a grammatical category morphologically marked on the verb typically realised by the binary opposition: imperfective (GLEDATI - WATCH) vs. perfective (ODGLEDATI - be watching) verbs.
} 
in 3 other examples, including (8s), a different explanation may be offered: it is best accounted for by the translator's choice to keep pragmatic equivalence in translation.

(8) Your registration number will do. (SAT)

(8s) Dovoljan mi je i broj tablica. (suB: 86)

The probability reading is retained when mood and modality markers appear in translation. With the conditional present of the main verb, in (9s) and 3 other examples in our data, the possibility meaning appears to be salient. Hence, the lower degree of the speaker's commitment to the realisation of the future event is indicated.

(9) It really will be much too messy. (UNC)

(9s) To bi zaista bio prevelik haos. (BU: 313)

By contrast, a high degree of commitment is clear when epistemic modality markers occur in translations. Both the indicative present and future 1 may be modified by adverbs: sigurno 'certainly, surely' occurs with these verb forms in 2 and 4 instances respectively, whereas svakako appears in one instance with future 1. In (10s) and (11s), the semantic domain is retained in translation, yet modality strength is altered. The adverb of certainty sigurno, which occupies the highest point of the epistemic scale on a par with the epistemic modal MORATI 'MUST', emphasises the belief of the speaker, thereby placing greater certainty on the part of a speaker and adding stronger epistemic strength in translations. The highest level of certainty, or the strongest commitment, is indicated by the modified present tense in (10s) and the similar effect is achieved by employing the modal verb MORATI in one example (12s). Conversely, the detachment from certainty is achieved by using the modal verb TREBATI 'NEED', which is the case in one instance in our data (13s). Given the verb form in (13), the modal expresses what is necessary to expect based on the natural course of events.

(10) He'll be in a state of mourning. (UNC)

(10s) Sigurno je u žalosti. (Bu: 142)

(11) She'll want to show him the proofs... (SAT)

(11s) Ona će svakako želeti da mu pokaže svoju korekturu... (suB: 183)

(12) Blues guitarists will be found other employment. (SAT)

(12s) Bluz gitaristi će morati da potraže druge poslove. (suB: 36)

(13) My parents will be arriving at any moment! (UNC)

(13s) Moji roditelji treba da stignu svakog časa. (BU: 530)

The modality of wILL is beyond dispute when it has non-future time reference. In this uncontroversial epistemic use, predictability wILL indicates a reasonable conclusion based on what is usually the case or what is reasonable to expect (Palmer 1986: 62). As regards the scalar character of epistemic modality, predictability wILL falls between a weak epistemic MAY and a strong epistemic MUST. In this respect, it closely corresponds 
to the Serbian future 1 form of BITI 'BE' (Trbojević-Milošević 2004: 139-141) which occurs as a TE of wILL in only one instance in which it refers to the past proposition (14s). In 6 other instances, a modal qualification of predictability wILL is conveyed with modal adverbs. Since the Serbian verb form has modal meaning paraphrased by maybe, probably (Trbojević-Milošević 2004: 141), the modality of wiLl is retained in the translations containing the adverb with this meaning, i.e. verovatno, as (15s) illustrates.

(14) ...they'll have seen things from a slightly different angle. (UNC)

(14s) ... biće da su sve to videli iz malo drugačijeg ugla. (BU: 118)

(15) Now Strauss will be dousing his head under the tap... (SAT)

(15s) Sada Straus verovatno kvasi glavu ispod česme... (suB: 105)

(16) But he'll be there already. (UNC)

(16s) Ali, on je već sigurno tamo. (BU: 480)

It is questionable, though, whether more frequent translations containing sigurno, including (16s), allow for the same interpretation due to the reasons discussed above. However, this observation may not be conclusive as Leech (2004: 86), for instance, argues that in similar cases MUST could replace wILL with a little change of effect. Regardless of this, there are grounds to claim that a shift in the strength of modal meaning can be noticed in (16s). In contrast, the loss of original meaning cannot be contradicted in one instance of rendering predictability WILL with the indicative present tense.

\subsection{Dynamic wILL}

Dynamic meanings of wILL are strongly related to its etymology as it derives from Old English lexeme meaning WANT TO, DESIRE and INTEND TO (Klinge 2005; Salkie 2010). Volition is considered a subject-oriented meaning dealing with the potentiality of an activity resulting from the subject's willingness/readiness (see Radovanović 2017). As an umbrella term, volition covers three senses: intention, willingness and insistence (Leech 2004: 85-88). In general, Serbian translations rarely reveal these subtle nuances of dynamic meaning as future 1 features as a typical TE regardless of the type of the subject. This is not surprising since this verb form also has the capacity for a modal transposition so that it can denote intention, among other multiple modal notions (Piper et al. 2005: 441-443). Intention, or intermediate volition (Leech 2004: 87 ), appears as a salient meaning of the TE of ' $l l$ in (17s). Typically, translations, as well as source examples, convey a promise, a threat, an offer or a shared decision. In view of the increasing syntactic layering of future 1, the syntactic form may be taken to signal dynamic modality. Although the use of $d a+$ present instead of the infinitive, 
so-called futuroid, is not in line with the normative rules (Piper et al. 2005: 327), it is not uncommon, as $(5 \mathrm{~s})$ and $(17 \mathrm{~s})$ illustrate.

(17) ... I won't go, I'll just rest. (UNC)

(17s) ... né́u da idem, samo ću da se odmaram. (BU: 248)

However, the TE of won't in (17s) is not considered to be the negative form of future 1 but the negated present of the verb HTETI 'WANT' with a voluntative meaning (Piper et al. 2005: 443). In Serbian, HTETI can syntactically function either as a clitic or a fully conjugated form. From a grammatical point of view, it is a modal verb that has syntactic as well as semantic properties which are shared by its English counterpart WILL, as (18s) illustrates.

(18) I'll just say thank you again for everything. (UNC)

(18s) Hoću samo da vam još jednom zahvalim na svemu. (BU: 184)

(19) Will you do it for me and Bruno? (UNC)

(19s) A hoćete li to učiniti za mene i Bruna? (BU: 371)

Yet, the shared semantics is retained mostly when found in the negative $(17 \mathrm{~s})$ and interrogative contexts $(19 \mathrm{~s})$. In (17s) the verb form implies unwillingness or refusal on the part of the subject. In the interrogative contexts like (19s), HTETI, like its English counterpart, occurs in speech acts of requesting that allow for an interpretation in terms of volitional meaning. By supposedly questioning the addressee's willingness in (19) and (19s), the speaker is, in fact, requiring the addressee to perform some action, which makes the utterance "a politer substitute for an imperative" (Leech 2004: 88). Due to the differences in the politeness strategies between English and Serbian, two other options of rendering wILL in requests are found in our data: imperative and a Serbian modal MOĆI 'CAN'. ${ }^{13}$ Each occurs in one instance and serves as an option to further strengthen or downtone the illocutionary force of a request.

Other TEs of dynamic wILL are mainly used as devices to heighten the volitional meaning. Hence, the sense of refusal in (20) is conveyed by a lexical verb ODBITI 'REFUSE' in (20s), whereas the idiomatic phrase in (21s) indicates the absolute lack of the subject's willingness to perform a future action. The strong volitional meaning of insistence is stressed in rendering with a Serbian desiderative modal lexeme žELETI 'WISH' in (22s).

(20) One ... who won't read books... (SAT)

(20s) Nekoga ko... odbija da čita knjige... (suB: 29)

(21) He won't deny a thing. (SAT)

(21s) Ne pada mu napamet da bilo šta demantuje. (suB: 113)

(22) She won't see you. (UNC)

(22s) Ne želi da vas vidi. (BU: 347)

\footnotetext{
${ }^{13}$ MOĆi apperas as a TE of won't.
} 
Again, the Serbian present tense is used to convey the meanings of the dynamic WILL. It occurs in 8 examples, which are, admittedly, balancing between a predictive and a volitional reading. Hence, the analysis may lead to the conclusion that this verb form is subjected to some contextual restrictions: it is a common TE of wILL collocating with the $1^{\text {st }}$ person subjects and verbs indicating movement or meeting somebody socially, as exemplified by (23s) and (24s) respectively. In both examples, it appears as the best option to achieve a pragmatic equivalence.

(23) We'll go and sit in your room. (SAT)

(23s) Idemo sada da malo posedimo u tvojoj sobi. (suB: 149)

(24) I'll see you in Notting Hill around five. (SAT)

(24s) Vidimo se na Noting Hilu oko 5. (suB: 142)

Since the present tense in the non-referential uses denotes general statements and habitual actions, it is a suitable TE of the propensity wILL which is concerned with habitual or typical behaviour of animate subjects or general properties of inanimates (Palmer 1990: 136-137), as (25s) and (26s) illustrate. Given that propensity wILL could be substituted with the simple present with little effect (Huddleston and Pullum 2002: 194), the present tense occurs as an appropriate option in translation.

(25) He'll always keep hopeful right to the end. (UNC)

(25s) Uvek gaji nade do samog kraja. (Bu: 88)

(26) This entrance will take you into the kitchens. (UNC)

(26s) Ovaj ulaz vodi do kuhinja. (BU: 467)

\section{Conclusion}

The findings of this study have provided additional insights into the similarities and differences between English and Serbian in expressing temporal and modal meanings. The small-scale contrastive analysis has revealed 14 different morphosyntactic and lexical elements in Serbian which are used to convey the meanings of English wILL. These findings accord with earlier observations about the different tendencies of conveying modality in the two languages: whereas English has a highly developed set of modal verbs, Serbian tends to employ a variety of devices including the frequent uses of tenses in special modal functions. The analysis has confirmed that English and Serbian show typological similarities in expressing temporality and modality and that these semantic categories are expressed with different formal systems in the two languages (Novakov 2008; Prtljaga 2008; Radovanović 2017; TrbojevićMilošević 2004).

A greater variation is noticed with the TEs of the dynamic wILL which may be explained by the diversified nature of this semantic domain. Overall, the tense forms 
are the prevailing means of rendering the English auxiliary. As for the frequency of occurrences, the Serbian future 1 stands out as being by far the most often used TE of WILL, which testifies to the existence of close formal and semantic similarity between the two verb forms in the investigated languages. The analysis also reveals that the present tense is a common device for rendering English wILL, which can be explained by the great semantic potential of this verb form (Pilipović 2013). Because of a large array of non-temporal meanings assigned to these tense forms, they can capture both epistemic and dynamic meanings of the investigated auxiliary. Further, Serbian modality markers are recurrent in the translation of either epistemic or dynamic WILL, which further points to the modality character of the auxiliary.

In general, the findings suggest that the semantic values of wILL are largely maintained in the translation. However, the instances of the modal meaning left unexpressed and a shift to non-modal meaning are noted, specifically, in the case of the indicative present tense used as a TE. Other semantic peculiarities surfacing in the translation are related to the shift of the modality subtype or strengthening of the modal meaning. One reason behind this may be associated with the translator's preference as to which equivalence to maintain in translation since the choice whether to follow semantic, pragmatic, syntactic or stylistic equivalence may change within one text (Jaczscolt 2003). Further, this may be explained by a low degree of modality of predictability wILL. Another possible explanation might be that Serbian present tense is more frequently employed for expressing future events perceived as certain, which can account for its use as a TE in examples allowing for a volitional reading, but under some contextual restrictions as stated above. Therefore, it could be useful to investigate and compare its occurrence in translations of other English future-time reference forms, which could pave the way for some future research.

\section{References}

Bergs, A. (2010). Expressions of futurity in contemporary English: a Construction Grammar perspective. English Language and Linguistics, 14(2), 217-238.

Cochrane N. and D. Kalogjera (1987). The Future tense in Serbo-Croatian and English, In: R. Filpović (ed.), Kontrastivna anliza engleskog $i$ hravatskog ili srpskog jezika, vol III, 242-260, as reproduced in Novakov (2008), 64-75.

Collins, P. (2009). Modals and quasi-modals in English (No. 67). Amsterdam and New York: Rodopi.

Comrie, B. (1985). Tense (Vol. 17). Cambridge: Cambridge University Press. 
Depraetere, I. (2016). Modality. In: N. Riemer (ed.), The Routledge Handbook of Semantics, London and New York: Routledge Taylor and Francis Group, 370386.

Depraetere, I. and S. Reed (2006). Mood and Modality in English. In: B. Aarts and A. McMahon (eds.), The Handbook of English Linguistics, Blackwell Publishing Ltd., 269-290.

Đorđević, R. (1994). Uvod u kontrastiranje jezika. Beograd: Filološki fakultet Univerziteta u Beogradu.

Huddleston, R. and G. K. Pullum (2002). The Cambridge Grammar of the English Language. Cambridge: Cambridge University Press.

Jaszczolt, K. M. (2003). On Translating 'What Is Said': Tertium Comparationis in Contrastive Semantics and Pragmatics'. In: K. M. Jaszczolt and K. Turner (eds.), Meaning Through Language Contrast, vol. 2, Amsterdam: Benjamins, 441-462.

Johansson, S. (2007). Seeing through Multilingual Corpora: On the use of corpora in contrastive studies. Amsterdam/Philadelphia: John Benjamins Publishing Company.

Kalogjera, D. (1971). The Expression of Future Time in English and in SerboCroatian. Reports, 4, 50-71.

Klinge, A. (2005). Where there is a will, there is a modal. In: A. Klinge and H. H. Müller (eds.), Modality: Studies in Form and Function, London: Equinox Publishing, 169-186.

Leech, G. N. (2004). Meaning and the English Verb. Third edition. Harlow: Pearson Education Limited/Longman.

Novakov, P. (2008). A Guide to time and tense in English and Serbian. Novi Sad: Futura publikacije.

Palmer, F. R. (1974). The English Verb. London: Longman Group Ltd.

Palmer, F. R. (1986). Mood and Modality. Cambridge: Cambridge University Press.

Palmer, F. R. (1990). Modality and the English Modals. Second edition. New York and London: Longman Linguistics Library.

Pilipović, V. (2013). The Serbian present tense and its English equivalents in a narrative text. Facta universitatis-series: Linguistics and Literature, 11(1), 13-21.

Piper et al. (2005). Sintaksa savremenoga srpskog jezika. Prosta rečenica. (red. Milka Ivić). Beograd: Institut za srpski jezik SANU/Beogradska knjiga/ Matica srpska.

Prtljaga, J. (2008). Engleski modalni glagoli can i will u epistemičkoj i dinamičkoj upotrebi i njihovi ekvivalenti u srpskom jeziku (English modals can and will in epistemic and dynamic use and their equivalents in the Serbian language). Pedagoška stvarnost, LIV, 7-8, 730-746. 
Radovanović, A. (2017). Dynamic Modals-English and Serbian Contrasted. Facta universitatis-series: Linguistics and Literature, 15(2), 273-285.

Radovanović, A. M. (2018). Još jedan osvrt na futur u engleskom jeziku. Zbornik radova Filozofskog fakulteta u Prištini, 48(1), 3-21.

Salkie, R. (2010). Will: Tense or modal or both. English Language and Linguistics, $14,187-215$.

Sarkar, A. (1998). The conflict between future tense and modality: The case of will in English. University of Pennsylvania Working Papers in Linguistics, 5(2), 91-117.

Trbojević-Milošević, I. (2004). Modalnost, sud, iskaz, Beograd: Filološki fakultet.

Wekker, H. C. (1976). The expression of future time in contemporary British English: an investigation into the syntax and semantics of five verbal constructions expressing futurity. Doctoral dissertation, Amsterdam: Noord-Hollandsche Uitgeversmaatschappij. (26 January 2019) <https://repository.ubn.ru.nl/ bitstream/handle/2066/148585/mmubn000001_118138715.pdf>.

\section{Sources}

BU - Išiguro, K. (2003). Bez utehe. Preveo Nenad Tomović. Beograd: Plato.

SAT - McEwan I. Saturday. (16 October 2017) $<$ http://ebookscart.com/saturday-by-ian-mcewan-novel-pdf-download $>$.

SUB - Makjuan, I. (2006). Subota. Prevela Arijana Božović. Beograd: Paideia.

UNC - Ishiguro, K. Unconsoled. (10 November 2016) $<\mathrm{http}$ ://www.bgcapp.com/books/download/asin=0679735879andtype=stream $>$. 